\title{
Alpha-adrenergic mRNA subtype expression in the human nasal turbinate
}

\author{
[Expression du sous-type d'ARN messager alpha-adrénergique dans le cornet \\ nasal humain]
}

\author{
Mark Stafford-Smith MD, ${ }^{*}$ Raquel Bartz MD, ${ }^{*} \dagger$ Katrina Wilson, ${ }^{*}$ James N. Baraniuk MD, $\mathfrak{S}$
} Debra A. Schwinn MD* †‡

Purpose: Alpha-adrenergic receptor (AR) agonist drugs (e.g., epinephrine) are commonly used for upper airway procedures, to shrink the mucosa, retard absorption of local anesthetic agents, and improve visualization by limiting hemorrhage. Decongestant therapy often also includes $\alpha A R$ agonist agents, however overuse of these drugs (e.g., oxymetazoline) can result in chronic rhinitis and rebound increases in nasal secretion. Since current decongestants stimulate $\alpha$ ARs non-selectively, characterization of $\alpha A R$ subtype distribution in human airway (nasal turbinate) offers an opportunity to refine therapeutic targets while minimizing side-effects. We, therefore, investigated $\alpha A R$ subtype expression in human nasal turbinate within epithelial, duct, gland, and vessel cells using in situ hybridization.

Methods: Since sensitive and specific anti-receptor antibodies and highly selective $\alpha A R$ subtype ligands are currently unavailable, in situ hybridization was performed on sections of three human nasal turbinate samples to identify distribution of $\alpha A R$ subtype mRNA. Subtype specific ${ }^{35}$ S-labelled mRNA probes were incubated with nasal turbinate sections, and protected fragments remaining after RNase treatment analyzed by light and darkfield microscopy.

Results: In non-vascular tissue $\alpha_{I d}$ AR mRNA predominates, whereas notably the $\alpha_{2 c}$ is the only $\alpha A R$ subtype present in the sinusoids and arteriovenous anastamoses.

Conclusion: Combined with the current understanding that AR-mediated constriction of nasal sinusoids underpins decongestant therapies that minimize secretions and shrink tissues for airway procedures, these findings suggest that $\alpha_{2 c}$ AR subtypes provide a novel selective target for decongestant therapy in humans.

CAN J ANESTH $2007 / 54: 7 /$ pp 549-555
Objectif: Les médicaments agonistes des récepteurs alphaadrénergiques (AR) (par ex., l'épinéphrine) sont communément utilisés lors des interventions sur les voies aériennes supérieures, afin de rétrécir la muqueuse, de retarder l'absorption d'agents anesthésiques locaux et d'améliorer la visualisation en limitant l'hémorragie. Un traitement décongestionnant inclut également souvent des agents agonistes $\alpha A R$; toutefois, la surutilisation de ces médicaments (par ex., l'oxymétazoline) peut engendrer une rhinite chronique et l'augmentation rebond des sécrétions nasales lors de la cessation du traitement. Puisque les décongestionnants actuels stimulent les $\alpha A R$ de manière non-sélective, la caractérisation de la distribution des sous-types d' $\alpha A R$ dans les voies aériennes de l'homme (cornet nasal) offre la possibilité de perfectionner les cibles thérapeutiques tout en minimisant les effets secondaires. C'est pourquoi nous avons examiné l'expression des sous-types d' $\alpha A R$ au niveau du cornet nasal humain dans les cellules épithéliales, du canal, des glandes et des vaisseaux, à l'aide d'une hybridation in situ.

Méthode : Étant donné que des anticorps anti-récepteurs sensibles et spécifiques ainsi que des ligands très sélectifs des soustypes d' $\alpha A R$ sont disponibles actuellement, l'hybridation in situ $a$ été effectuée sur des sections de trois échantillons de cornet nasal humain afin d'identifier la distribution d'ARN messager des sous-types d' $\alpha A R$. Des sondes d'ARN messager marquées au ${ }^{35} \mathrm{~S}$ et spécifiques au sous-type ont été incubées avec des sections de cornet nasal, et les fragments protégés restants après le traitement à la ribonucléase ont été analysés par microscopie optique et sur fond noir.

Résultats: Dans les tissus non-vasculaires, l'ARN messager $A R$ $\alpha_{l d}$ est prédominant, alors que le $\alpha_{2 c}$ est notablement le seul sous-type d' $\alpha A R$ présent dans les sinusoïdes et les anastomoses artérioveineuses.

From the Departments of Anesthesiology, ${ }^{*}$ Pharmacology/Cancer Biology, \& Medicine (Pulmonary and Cardiology), $†$ and Surgery, $\ddagger$ Duke University Medical Center, Durham, North Carolina; and the Departments of Medicine and Pediatrics, $\$$ Georgetown University, Washington, DC, USA.

Address correspondence to: Dr. Mark Stafford-Smith, Department of Anesthesiology, Duke University Medical Center, Box 3094, DUMC, Durham, NC 27710, USA. Phone: 919-681-5046; Fax: 919-681-8993 ; E-mail: staff002@mc.duke.edu

Funding: This study was funded in part by NIH grant \#HL49103 (DAS) and an educational grant from Proctor \& Gamble. Tissue was provided by Drs. Rasmussen-Ortega and Stephen B. Liggett.

Accepted for publication February 16, 2007.

Revision accepted April 9, 2007. 
Conclusion: On considère maintenant que la constriction des sinus nasaux médiée par AR est à la base des thérapies de décongestion qui minimisent les sécrétions et rapetissent les tissus lors des interventions sur les voies aériennes. Ces résultats suggèrent donc que les sous-types d'AR $\alpha_{2 c}$ fournissent une nouvelle cible sélective pour les traitements de décongestion chez les humains.

A LPHA-ADRENERGIC receptors ( $\alpha$ ARs) are commonly used for upper airway procedures, to shrink the mucosa, retard absorption of local anesthetic agents, and improve visualization by limiting hemorrhage, and also play a key role in the pharmacologic treatment of nasal congestion, rhinorrhea, and epistaxis. Stimulation of $\alpha$-receptors on the nasal erectile apparatus leads to constriction of arteriovenous anastomoses and collapse of venous sinusoids (Figure 1). The result is a decrease in the thickness of the nasal mucosa and so an increase in the nasal cross-sectional area of airflow within the bony confines of the nostrils. These effects are mediated in vivo by the sympathetic innervation, and therapeutically by oral and topical sympathomimetics. Effects on epithelial cell ciliary function and glandular exocytosis have also been reported. ${ }^{1}$ Withdrawal of sympathetic effects leads to vasodilation of the arteriovenous anastomoses and engorgement of the venous sinusoids. The result is thickening of the nasal mucosa, reduction of cross-sectional area for airflow, and nasal obstruction. Prolonged use of topical sympathomimetics such as oxymetazoline and zylometazoline may lead to rebound vasodilation, ciliary dysfunction, and increased glandular secretion in the condition of rhinitis medicamentosa..$^{2-6}$

Nasal $\alpha$ ARs have been described previously. However, the specific $\alpha_{1}$ subtypes $\left(\alpha_{1 \mathrm{a}}, \alpha_{1 \mathrm{~b}}, \alpha_{1 \mathrm{~d}}\right)$ and $\alpha_{2}$ subtypes $\left(\alpha_{2 \mathrm{a}}\right.$ - formerly $\alpha_{2} \mathrm{Cl} 0, \alpha_{2 \mathrm{~b}}$ - formerly $\alpha_{2} \mathrm{C} 2, \alpha_{2 \mathrm{c}}$ - formerly $\left.\alpha_{2} \mathrm{C} 4\right)$ that are present and their differential distribution on the epithelium, submucosal glands, arteriovenous anastomoses, post-capillary venules that regulate vascular permeability and leukocyte infiltration, and venous sinusoids have not been determined. $^{7-9}$ Currently available partially selective $\alpha_{1}$ - and $\alpha_{2}$-agonists and endogenous norepinephrine are nonselective for these receptors. In addition, aAR subtype distribution is remarkably heterogenous among cell types in different tissues and mammalian species. ${ }^{10-13}$ We hypothesize that understanding the distribution of each receptor subtype on nasal tissues may lead to more specific decongestant targets capable of providing benefit while minimizing worrisome side-effects.

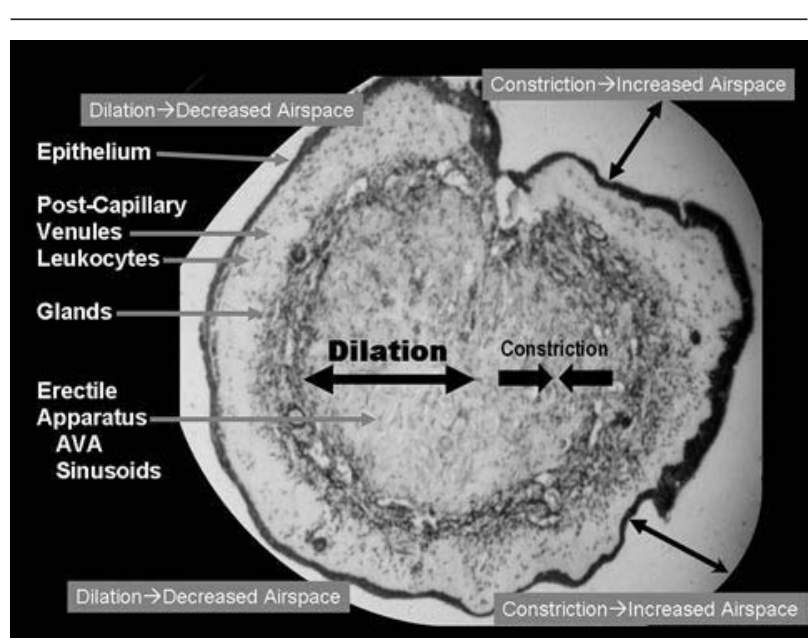

FIGURE 1 Diagrammatic representation of nasal turbinate cytoarchitecture. The nasal turbinates have concentric epithelial, superficial vascular, submucosal gland, and deep erectile tissues. Dilation of the venous sinusoids increases the thickness of the mucosa and decreases the cross-sectional area of airflow (left half of diagram). Vasoconstriction of the arteriovenous anastomoses and myoepithelial cells of the sinusoidal walls cause sinusoid collapse, thinning of the mucosa, and an increase in the cross-sectional area of airflow (right half of diagram).

Identifying cell specific distribution of $\alpha A R$ subtypes within nasal tissue should facilitate novel pharmacologic targeting directed at the common and vexing problem of nasal decongestion. Because highly subtype specific antibodies for $\alpha \mathrm{AR}$ subtypes remain unavailable, we examined $\alpha \mathrm{AR}$ subtype distribution using in situ hybridization on human nasal turbinate tissue.

\section{Materials and methods}

Nasal turbinate tissue preparation and detection of $\alpha A R$ subtype $m R N A$

Institutional Review Board (IRB) approval and individual patient consent was obtained for access to explanted nasal turbinate tissue from three individuals undergoing endoscopic nasal surgery; in addition, IRB approval was obtained at the institution where laboratory studies were performed. Tissue samples were immediately placed in liquid nitrogen and stored at $-70^{\circ} \mathrm{C}$. Ten $\mu \mathrm{m}$ horizontal frozen sections were cut on a cryostate (Leitz Kryostat 1720 digital, Wetzlar, Germany) using a $-20^{\circ} \mathrm{C}$ block, thaw mounted onto sialylated microscope slides, and stored at $-70^{\circ} \mathrm{C}$ with desiccant until further use. Radiolabelled single strand- 
ed sense (control) and antisense (specific) RNA probes were made using linearized cDNA constructs, $\left[{ }^{35} \mathrm{~S}\right]$ aUTP (Dupont, NEN, Boston, MA, USA) and either SP6 or T7 RNA polymerase, as previously described; mRNA probes and controls for in situ experiments have been previously validated in our laboratory. ${ }^{12-14}$

\section{In situ hybridization}

Frozen slide mount sections were warmed to room temperature then rinsed for five minutes with $2 \times$ SSC $(1 \times \mathrm{SSC}=0.15 \mathrm{M} \mathrm{NaCl}, 0.04 \mathrm{M} \mathrm{Na}$ citrate, $\mathrm{pH}$ 7.2). No permeabilization or prehybridization steps were performed. Hybridization buffer (0.02M DTT, Ix Denhart's solution (Sigma, St. Louis, MO, USA), $1 \mathrm{mg} \cdot \mathrm{mL}^{-1}$ salmon sperm DNA (Sigma) heated to $80^{\circ} \mathrm{C}$ before use, $50 \mu \mathrm{g} \cdot \mathrm{mL}^{-1}$ transfer RNA (Sigma), $2 \times$ SSC, $50 \%$ formamide, $9 \%$ dextran sulfate), and $5000-7000 \mathrm{cpm} \cdot \mu \mathrm{L}^{-1}$ linearized radiolabelled probe were applied to the slides. The slides were then incubated at $50^{\circ} \mathrm{C}$ overnight in sealed plastic containers lined with Whatman filter paper soaked with $50 \%$ formamide in $2 \times$ SSC buffer to prevent evaporation of hybridization solution. To remove non-specific binding, slides were washed as follows: sequential immersion in $1 \mu \mathrm{L} \cdot \mathrm{mL}^{-1} \beta$-mercaptoethanol solutions in $2 \times \operatorname{SSC}\left(50^{\circ} \mathrm{C}\right.$, brief dip) and $50 \%$ formamide in $2 \times \operatorname{SSC}\left(50^{\circ} \mathrm{C}\right.$, ten then $\left.20 \mathrm{~min}\right)$, followed by RNase treatment using $10 \mu \mathrm{g} \cdot \mathrm{mL}^{-1}$ RNase in $2 \times \mathrm{SSC}$ $\left(35^{\circ} \mathrm{C}, 30 \mathrm{~min}\right)$. Subsequent washes included the following: $2 \times$ SSC (RT, five minutes), $50 \%$ formamide in $2 \times \operatorname{SSC}\left(50^{\circ} \mathrm{C}\right.$, five minutes), and $2 \times \operatorname{SSC}$ (ten minutes), followed by dehydration steps using twominute immersions each in $0.3 \mathrm{M}$ ammonium acetate solutions containing $50 \%, 70 \%$, and finally pure $100 \%$ ethanol. After air drying for 30-60 min, slides were then dipped in warm $\left(40^{\circ} \mathrm{C}\right)$ autoradiography emulsion (Kodak NTB2, Rochester, NY, USA) in a darkroom illuminated with a Kodak safelight \#2, dried for several hours in the dark, and placed in light-sealed slide boxes with desiccant at $4^{\circ} \mathrm{C}$ for four weeks. After warming for $90 \mathrm{~min}$ to room temperature, exposed slides were developed under a safelight by sequential immersion in fresh D19 developer (Kodak) mixed 1:1 with distilled water $\left(\mathrm{dH}_{2} \mathrm{O}\right.$ at $15^{\circ} \mathrm{C}$, four minutes $)$ followed by room temperature immersions in $\mathrm{dH}_{2} \mathrm{O}(20$ sec), fixer (Kodak) (five minutes), and $\mathrm{dH}_{2} \mathrm{O}$ rinses $(3 \times$ five minutes). Slides were counterstained with hematoxylin and eosin, dehydrated in an ascending ethanol and xylene series, and coverslips added. Dry slides were examined and photographed under light and dark field microscopy using Lietz Leica (Wetzlar, Germany), WILD M420 (low power), and DMR (high power) microscopes at 100X.
TABLE I Darkfield and brightfield semiquantitative grading system to assess relative presence of $\alpha \mathrm{AR}$ subtype mRNA within human nasal turbinate

\begin{tabular}{lll}
\hline Grade & Darkfield & Brightfield \\
\hline 0 & background & background \\
$+/-$ & $\begin{array}{l}\text { very low density of } \\
\text { individual grains }\end{array}$ & background \\
+ & $\begin{array}{l}\text { low density of individual grains } \\
++\end{array}$ & $\begin{array}{l}\text { moderate density of grains } \\
\text { patterns of individual } \\
\text { grains }\end{array}$ \\
+++ & high density grains and clusters & $\begin{array}{l}\text { clusters of grains } \\
\text { high density of grains }\end{array}$ \\
++++ & high density clusters & \\
\hline$\alpha \mathrm{AR}=$ alpha-adrenergic receptor &
\end{tabular}

$\alpha \mathrm{AR}=$ alpha-adrenergic receptor.

\section{Controls}

In order to ensure that detected signal represents specific probe hybridization, several positive and negative controls were performed. Since human nasal turbinate tissue was limited, each probe used in this study was carefully tested in experiments with human spinal cord using antisense human $\beta$-actin as a positive control. ${ }^{12,13}$ Negative controls included verifying lack of signal with sense probes and demonstration of loss of signal in known positive samples exposed to excess RNase [in situ experiments using excess $\left(50 \mu \mathrm{g} \cdot \mathrm{mL}^{-1}\right)$ RNase in washes]. Controls for $\alpha A R$ subtype specificity of antisense probes included simultaneously performed in situ experiments with known positive and negative non-nasal turbinate tissues.

\section{Detection and analysis}

Due to the thickness of the nasal turbinate specimens, a standard quantitative method previously used in our lab was found to be unreliable. ${ }^{13}$ Instead, relative quantification of mRNA probe hybridization was recorded by two separate blinded observers using the presence of silver grains within specific nasal turbinate specific cell types - epithelium, ducts, glands, and/or vessels. Negative controls included sense probe experiments on the same tissue. Sections were scored by the intensity of silver grain density relative to background (Table I).

\section{Results}

There was excellent concordance (> 90\%) between the two observers' independent scoring of relative intensities of silver grains for the different nasal turbinate samples. Furthermore, there was no evidence of non-specific signalling in positive control samples. Table II summarizes observations for specific cell types and all $\alpha A R$ subtype mRNAs. While all six AR subtype mRNAs are present in human nasal turbinate, 
TABLE II Relative presence of $\alpha A R$ subtype mRNA within human nasal turbinate

\begin{tabular}{|c|c|c|c|c|c|c|c|c|c|c|}
\hline \multirow[t]{2}{*}{$\alpha A R$ subtype } & \multicolumn{3}{|c|}{ Epithelium } & \multicolumn{2}{|c|}{ Ducts } & \multicolumn{2}{|c|}{ Glands } & \\
\hline & $G C$ & $C C$ & $B C$ & $S D$ & $M D$ & $S G$ & $M G$ & $P C V$ & $\operatorname{Sin}$ & s $A V A$ \\
\hline$\alpha_{1 a}$ & + & 0 & 0 & 0 & 0 & 0 & ++ & 0 & 00 & \\
\hline$\alpha_{1 b}$ & 0 & + & 0 & + & 0 & ++ & +++ & 0 & 0 & 0 \\
\hline$\alpha_{1 \mathrm{~d}}$ & +++ & +++ & +++ & +++ & +++ & ++++ & ++++ & 0 & 00 & \\
\hline$\alpha_{2 a}$ & 0 & + & 0 & ++ & + & +++ & + & 0 & 0 & 0 \\
\hline$\alpha_{2 b}$ & 0 & + & 0 & ++ & + & +++ & + & 0 & 0 & 0 \\
\hline$\alpha_{2 c}$ & + & ++ & $+/-$ & ++ & ++ & +++ & ++ & 0 & ++ & ++ \\
\hline
\end{tabular}

individual subtype location tends to be restricted to specific cell types (Table II). Representative light and dark field images of nasal turbinate epithelium are presented in Figure 2. In non-vascular tissue, the overall predominant $\alpha A R$ subtype mRNA is the $\alpha_{1 d}$; this subtype is present in epithelium, ducts and glands. Less generalized presence of other $\alpha_{1}$ mRNAs occurs in specific cell types such as goblet cells and mucous glands $\left(\alpha_{1 \mathrm{a}}\right)$ and ciliated cells, serous ducts and glands, and mucous glands $\left(\alpha_{1 b}\right)$. Within the $\alpha_{2}$ AR family, the $\alpha_{2 c}$ is present in all epithelial cells, ducts, and glands. In addition, $\alpha_{2 c} \mathrm{ARs}$ are present in sinusoids and arteriovenous anastamoses, where it is the only $\alpha A R$ present. In contrast, $\alpha_{2 \mathrm{a}}$ and $\alpha_{2 \mathrm{~b}}$ signal is more restricted.

\section{Discussion}

In this study we describe, for the first time, $\alpha A R$ mRNA subtype distribution in ten cell types present in human nasal mucosa. By demonstrating cell and subtype specific expression using in situ hybridization, we confirm the hypothesis that $\alpha A R$ subtype distribution in the nasal mucosa is heterogenous. Such findings provide new mechanistic insight regarding potential roles of individual $\alpha$ AR subtypes in human nasal mucosa and suggest more selective targets for nasal decongestion therapy.

In spite of the importance of nasal tissue as a pharmacologic target, little information is available regarding $\alpha A R$ distribution in this tissue. For many years investigators have assumed beneficial effects of $\alpha \mathrm{AR}$ agonists on nasal tissues resulted from vasoconstrictor effects, essentially dampening fluid flow through this tissue. ${ }^{2-4}$ Indeed, nasal mucosa is highly vascular. Nasal vessels include arteries and arterioles (resistance vessels), arteriovenous connections, subepithelial and periglandular capillary networks which drain into collecting veins and venous sinusoids (capacitance vessels), and finally the sphenopalatine vein. ${ }^{15,16}$

Initially investigating $\alpha \mathrm{AR}$ effects on vascular tone, Ichimura et al. ${ }^{17}$ demonstrated the presence of postsynaptic $\alpha_{1}$ ARs as well as pre- and postsynaptic $\alpha_{2}$ ARs in canine nasal vascular smooth muscles using pharmacologic approaches. These findings suggested that stimulation of either $\alpha_{1}$ or $\alpha_{2}$ ARs would be expected to provide vascular smooth muscle contraction. Using guinea pig nasal mucosa, Tanimitsu et al. ${ }^{18}$ suggested that activation of $\alpha_{1 \mathrm{a}}$ ARs result in contraction of nasal mucosa vasculature. This is in contrast to pharmacologic studies in dogs suggesting both $\alpha_{1}$ and $\alpha_{2}$ AR mediate vasoconstriction. ${ }^{19}$ This disparity between guinea pig and dog in nasal turbinate $\alpha A R$ distribution is not surprising, given the marked species variability in overall expression of AR subtypes, and highlights the importance of studies using human tissue.

Studies in humans suggest the primary mechanism underlying nasal decongestion appears to be venous constriction of the collecting veins and sinusoids; ${ }^{15,16,20-23}$ such constriction decreases engorgement of nasal mucosa, attenuating alterations in nasal anatomy that have been shown to alter nasal 

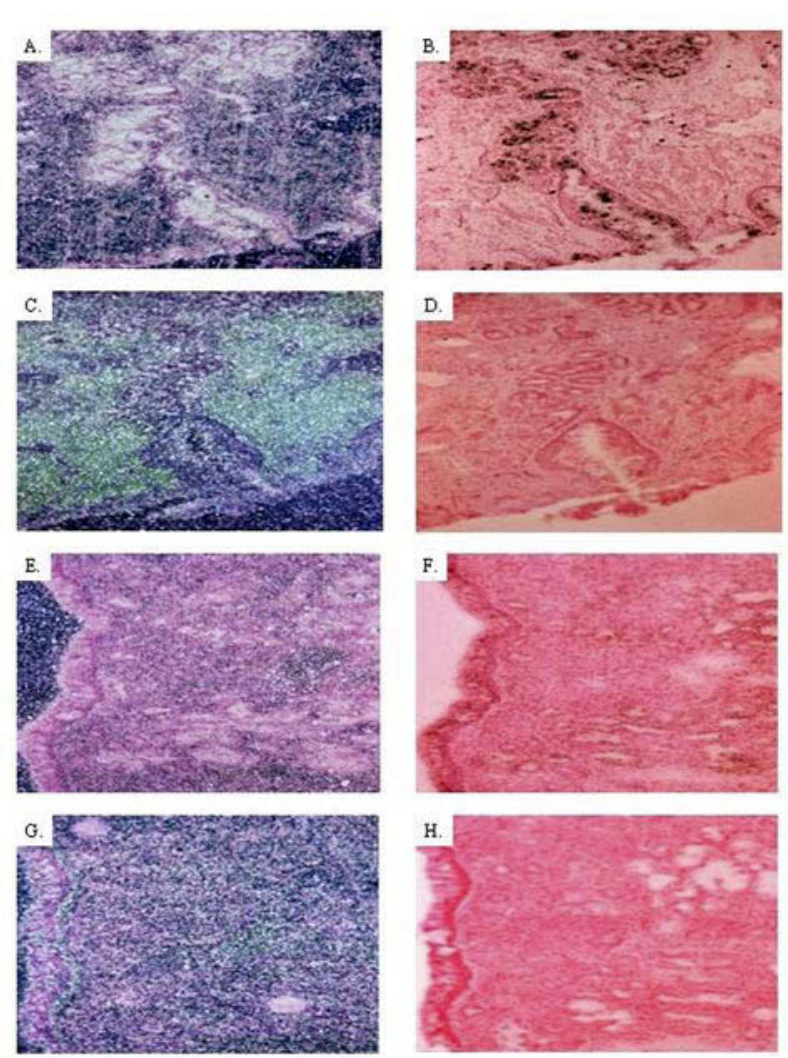

FIGURE 2 Representative examples of in situ hybridization experiments in human nasal turbinate tissue. The $\alpha_{1 d}$-antisense probe demonstrates a high density signal by darkfield (A, whitish silver grains in glands, ducts, and epithelial cells) and lightfield (B, black grains) microscopy. High density signal is absent in equivalent experiments in adjacent tissue sections ( $\mathrm{C}$ and $\mathrm{D}$, respectively) using the $\alpha_{1 d}$-sense (control) probe. Similar experiments using $\alpha_{2 c^{-}}$ antisense probe demonstrate more moderate density signal by darkfield (E) and lightfield (F, light brown) microscopy, which is absent in equivalent experiments ( $\mathrm{G}$ and $\mathrm{H}$, respectively) using the $\alpha_{2 c}$-sense (control) probe. Cell type specificity in $\alpha_{1}$ and $\alpha_{2}$ signalling is evident in epithelial, duct and glandular regions, and is also visible in vascular tissues at higher levels of magnification (see Table II).

air flow. ${ }^{22,24,25}$ Our results are the first to address this question in humans at an $\alpha \mathrm{AR}$ subtype level, revealing presence of only $\alpha_{2 c} \mathrm{AR}$ mRNA in human nasal sinusoids and arteriovenous anastamoses. In the $\alpha A R$ family, $\alpha_{2}$ ARs are primarily responsible for venous (rather than arterial) constriction. This is true for a wide range of venous capacitance beds such as saphenous vein, ${ }^{26-}$ 28 dermal veins, ${ }^{28,29}$ and nasal mucosa. ${ }^{15,16,20,21,30}$ Our findings suggest an important and unique role for the $\alpha_{2 c}$ subtype in nasal sinusoids, making this receptor a new subtype selective target for decongestion.
In addition to sinusoidal constriction as the main mechanism for decongestant action, other mechanisms have been shown to contribute to a lesser extent; such decongestant targets include $\alpha_{1}$ AR-mediated arteriolar constriction. ${ }^{15,20,30}$ Andersson and Bende ${ }^{2}$ studied specific $\alpha A R$ effects using topical application of $\alpha A R$ agonists and measurement of Xenon washout in the nasal mucosa of 43 healthy subjects. Findings from this study prompted the authors to conclude that vasoconstrictor actions of phenylephrine are likely due to preferential action on $\alpha_{1}$ ARs whereas oxymetazoline action is due to $\alpha_{2} \mathrm{AR}$ activation.

While vasoconstriction is thought to be the major effect of topical $\alpha \mathrm{AR}$ agonists, ${ }^{3}$ other functional targets are possible. For example, $\alpha_{1}$ AR-mediated slowing of nasal ciliary beat frequency, ${ }^{31}$ as well as effects on mucosal gland functioning, ${ }^{32}$ provides two alternative targets. Alpha AR agonists have been shown to decrease the secretion of serous cell products from human nasal mucosa although underlying mechanisms currently remain unknown. ${ }^{2,4}$ The strong presence of $\alpha_{1 d}$ mRNA in epithelial cells, serous, and mucous cells of glands and ducts suggests this adrenergic receptor subtype may play a role in nasal secretions from these cells. Supporting this contention, $\alpha_{1} \mathrm{AR}$ antagonists (often administered to treat prostate disease) tend to increase nasal secretions. ${ }^{33}$ Since the $\alpha_{1 a / d}$ selective antagonist tamsulosin also has this effect, this limits the possible subtypes involved to the $\alpha_{1 \mathrm{a}}$ or $\alpha_{1 \mathrm{~d}}$. Our demonstration that only $\alpha_{1 d}$ mRNA is present on epithelium, ducts, and glands strongly suggests that the $\alpha_{1 \mathrm{~d}} \mathrm{AR}$ subtype is important in nasal secretion. This pathway of exocytosis represents a secondary mechanism (beyond simple vasoconstriction) for the efficacy of non-subtype selective $\alpha_{1}$ AR agonists currently being marketed as nasal sprays and oral therapies. However, since rhinnorhea is a common side-effect of overuse of oxymetazoline nose sprays, one might hypothesize that avoiding $\alpha_{1 \mathrm{~d}} \mathrm{AR}$ effects might minimize this possible complication.

In spite of our novel findings, some limitations to our study exist. Because $10 \mu \mathrm{m}$ thick nasal turbinate slices cut through multiple cell layers, precise determination of exact amounts of tissue mRNA was precluded. Instead, we relied on two blinded expert observers; while there was excellent concordance between observers, it should be remembered that our findings represent relative, and not absolute, quantitation. Another possible limitation is that nasal turbinate explants came from patients undergoing functional endoscopic surgery, a surgery often employed for chronic sinusitis. These patients may have been taking medications that may have altered levels of receptor 
expression and cellular distribution. Countering this possibility are previous studies suggesting no major changes occur in expression of nasal turbinate $\alpha$ ARs $\left(\begin{array}{lll}\alpha_{1} & p s & \alpha_{2}\end{array}\right)$ with chronic sinusitis. ${ }^{7}$ Obtaining fresh human nasal tissue from individuals without disease is ethically challenging, making the optimal control study almost impossible. Further, it should be remembered that decongestants are most often utilized by individuals with diseased nasal mucosa; therefore, our findings are important for the target patient population in any case. Finally, because of lack of monoclonal and/or highly specific polyclonal antibodies against specific $\alpha A R s$, we cannot be entirely sure the presence of mRNA correlates with the presence of receptor protein at the cell surface. However some of our key findings suggest the presence of only one (with demonstrated absence of the other five $\alpha A R$ subtypes) $\alpha A R$ mRNA species. In these cases, general supportive pharmacologic data $\left(\begin{array}{llll}\alpha_{1} & v s & \alpha_{2}\end{array}\right)$ exist, suggesting the mRNA is expressed at a protein level and functional. Hence, we have confidence in our major key findings that only $\alpha_{2 c} \mathrm{AR}$ mRNA is noted in nasal sinusoids, the precise tissue thought key in decongestant activity. Since human tissue samples were quickly frozen after explantation and clear $\alpha \mathrm{AR}$ subtypes are present in each sample (documented by each observer), it is highly unlikely that our negative findings for some subtypes resulted from RNA degradation. Further studies evaluating specific receptor protein expression and functional effects (using antibodies and/or more highly selective ligands as they become available) will be helpful in confirming our findings.

In summary, this is the first study to report cell type-specific distribution of $\alpha A R$ mRNAs. We confirm that $\alpha_{1}$ and $\alpha_{2} \mathrm{AR}$ mRNA is present in human nasal turbinate epithelium, ducts, glands, and vessels, with selectivity for distinct subtypes limited to specific cell types. For instance, $\alpha_{2 c} \mathrm{AR}$ mRNA is the only $\alpha A R$ mRNA present in nasal venous sinusoids. These findings suggest that specific $\alpha_{2 c} \mathrm{AR}$ agonists might provide targeted decongestant therapy with fewer side-effects.

\section{Acknowledgement}

The authors acknowledge with thanks the editorial assistance of Cheryl J. Stetson.

\section{References}

1 Mullol J, Raphael GD, Lundgren JD, et al. Comparison of human nasal mucosal secretion in vivo and in vitro. J Allergy Clin Immunol 1992; 89: 584-92.

2 Andersson KE, Bende M. Adrenoceptors in the control of human nasal mucosal blood flow. Ann Otol Rhinol
Laryngol 1984; 93(2 Pt 1): 179-82.

3 Malm L. Vascular and secretory effect of adrenoceptor agonists and peptides in the nose. Eur J Respir Dis Suppl 1983; 128(Pt 1): 139-42.

4 Graf $P$. Rhinitis medicamentosa: a review of causes and treatment. Treat Respir Med 2005; 4: 21-9.

5 Talaat M, Belal A, Aziz T, Mandour M, Maher A. Rhinitis medicamentosa: electron microscopic study. J Laryngol Otol 1981; 95: 125-31.

$6 \mathrm{Su} X Y, \mathrm{Li}$ Wan Po A. The effect of some commercially available antihistamine and decongestant intra-nasal formulations on ciliary beat frequency. J Clin Pharm Ther 1993; 18: 219-22.

7 van Megen YJ, Klaassen AB, Rodrigues de Miranda $J F$, van Ginneken CA, Wentges BT. Alterations of adrenoceptors in the nasal mucosa of allergic patients in comparison with nonallergic individuals. J Allergy Clin Immunol 1991; 87: 530-40.

8 Van Megen YJ, Van Ratingen CJ, Klaassen AB, Rodrigues de Miranda JF, Van Ginneken CA, Wentges $B T$. Biochemical and autoradiographic analysis of betaadrenoceptors in rat nasal mucosa. Eur J Pharmacol 1990; 182: 515-25.

9 Ishibe T, Yamashita T, Kumazawa T, Tanaka C. Adrenergic and cholinergic receptors in human nasal mucosa in cases of nasal allergy. Arch Otorhinolaryngol 1983; 238: 167-73.

10 Price DT, Lefkowitz RJ, Caron MG, Berkowitz D, Schwinn DA. Localization of mRNA for three distinct alpha 1-adrenergic receptor subtypes in human tissues: implications for human alpha-adrenergic physiology. Mol Pharmacol 1994; 45: 171-5.

11 Rudner XL, Berkowitz DE, Booth JV, et al. Subtype specific regulation of human vascular alpha(1)-adrenergic receptors by vessel bed and age. Circulation 1999; 100: 2336-43.

12 Stafford-Smith M, Schambra UB, Wilson KH, et al. Alpha 2-adrenergic receptors in human spinal cord: specific localized expression of mRNA encoding alpha 2 -adrenergic receptor subtypes at four distinct levels. Brain Res Mol Brain Res 1995; 34: 109-17.

13 Stafford-Smith M, Schambra UB, Wilson KH, Page SO, Schwinn DA. Alphal-adrenergic receptors in human spinal cord: specific localized expression of mRNA encoding alphal-adrenergic receptor subtypes at four distinct levels. Brain Res Mol Brain Res 1999; 63: 254-61.

14 Price DT, Chari RS, Berkowitz DE, Meyers WC, Schwinn DA. Expression of alpha 1-adrenergic receptor subtype mRNA in rat tissues and human SK-N-MC neuronal cells: implications for alpha 1-adrenergic receptor subtype classification. Mol Pharmacol 1994; 46: $221-6$. 
15 Corboz MR, Varty LM, Rizzo CA, et al. Pharmacological characterization of alpha 2-adrenoceptor-mediated responses in pig nasal mucosa. Auton Autacoid Pharmacol 2003; 23: 208-19.

16 Wang $M$, Lung MA. Adrenergic mechanisms in canine nasal venous systems. Br J Pharmacol 2003; 138: 14555 .

17 Ichimura K, Jackson RT. Evidence of alpha 2-adrenoceptors in the nasal blood vessels of the dog. Arch Otolaryngol 1984; 110: 647-51.

18 Tanimitsu N, Yajin K, Sasa M, Tsuru H. Alpha(1)adrenoceptor subtypes and effect of alpha(1A)-adrenoceptor agonist NS-49 on guinea pig nasal mucosa vasculature. Eur J Pharmacol 2000; 387: 73-8.

19 Berridge TL, Roach AG. Characterization of alphaadrenoceptors in the vasculature of the canine nasal mucosa. Br J Pharmacol 1986; 88: 345-54.

20 Corboz MR, Rivelli MA, Varty L, et al. Pharmacological characterization of postjunctional alpha-adrenoceptors in human nasal mucosa. Am J Rhinol 2005; 19 : 495-502.

21 Ichimura K, Chow MJ. Postjunctional alpha 2-adrenoceptors in blood vessels of human nasal mucosa. Arch Otorhinolaryngol 1988; 245: 127-31.

22 Cole P, Haight JS, Cooper PW, Kassel EE. A computed tomographic study of nasal mucosa: effects of vasoactive substances. J Otolaryngol 1983; 12: 58-60.

23 Kristiansen AB, Heyeraas KJ, Kirkebo A. Increased pressure in venous sinusoids during decongestion of rat nasal mucosa induced by adrenergic agonists. Acta Physiol Scand 1993; 147: 151-61.

24 Bende M, Elner A, Oblin P. The effect of provoked allergic reaction and histamine on nasal mucosal blood flow in humans. Acta Otolaryngol 1984; 97: 99-104.

25 Graf P, Toll K, Palm J, Hallen H. Effects of sustainedrelease oral phenylpropanolamine on the nasal mucosa of healthy subjects. Acta Otolaryngol 1999; 119: 83742.

26 Rizzo CA, Ruck LM, Corboz MR, et al. Postjunctional alpha(2C)-adrenoceptor contractility in human saphenous vein. Eur J Pharmacol 2001; 413: 263-9.

27 Gavin KT, Colgan MP, Moore D, Shanik G, Docherty $J R$. Alpha 2C-adrenoceptors mediate contractile responses to noradrenaline in the human saphenous vein. Naunyn Schmiedebergs Arch Pharmacol 1997; 355: 406-11.

28 Chotani MA, Mitra S, Su BY, et al. Regulation of alpha(2)-adrenoceptors in human vascular smooth muscle cells. Am J Physiol Heart Circ Physiol 2004; 286: H59-67.

29 Flavaban NA. Phenylpropanolamine constricts mouse and human blood vessels by preferentially activating alpha2-adrenoceptors. J Pharmacol Exp Ther 2005;
313: 432-9.

30 Johannssen V, Maune S, Werner JA, Rudert H, Ziegler $A$. Alpha 1-receptors at pre-capillary resistance vessels of the human nasal mucosa. Rhinology 1997; 35: 161-5.

31 Curtis LN, Carson JL. Computer-assisted video measurement of inhibition of ciliary beat frequency of human nasal epithelium in vitro by xylometazoline. J Pharmacol Toxicol Methods 1992; 28: 1-7.

32 Loth $S$, Bende $M$. The effect of topical phenylpropanolamine on nasal secretion and nasal airway resistance after histamine challenge in man. Clin Otolaryngol Allied Sci 1985; 10: 15-9.

33 Malm L, McCaffrey TV, Kern EB. Alpha-adrenoceptormediated secretion from the anterior nasal glands of the dog. Acta Otolaryngol 1983; 96: 149-55. 